\title{
THE SPECTER OF TOKKIE-FACING THE PAST, INVENTING THE FUTURE: ZOË WICOMB'S PLAYING IN THE LIGHT
}

\author{
Anette Horn \\ University of the Witwatersrand \\ anette.horn@wits.ac.za
}

\begin{abstract}
Zoë Wicomb's novel Playing in the Light, published in 2006, is set in Cape Town in the 1990s at the time of the Truth and Reconciliation Commission (TRC). Its protagonist Marion Campbell, who is the owner of a successful travel agency, is suddenly haunted by the specter of a young woman she does not know, but who seems familiar nevertheless, on the ocean between her flat and Robben Island-where political prisoners were kept-and who seems to strangle her in the muslin curtains of her four-poster bed at night. This face becomes confused with the repressed memory of the family servant of Marion's childhood, Tokkie. When Marion sees the young woman's face again on the title page of a daily newspaper, she discovers that the woman of her nightmares, Patricia Williams, was an activist in the anti-apartheid struggle who was tortured by the police and has just told her story before the TRC. Yet the conflated specters of Tokkie and Patricia Williams set off a process whereby Marion has to confront her own repressed past as a "play white," i.e., someone who-although of colored origin-was light-skinned enough to pass for white. Marion has to disentangle the web of lies that her biography was until now and find a standpoint from which to invent a future for herself that will be free of the shame which the fear of her colored status becoming public imposed on her. Using Derrida's Specters of Marx as a theoretical framework, this paper explores how the past is imbricated in the present and how-only by facing it—is the fiction of a fixed, unified self broken up, making room for inventions of the future. This is the emancipation from racial classification which the New South Africa made possible through the TRC.
\end{abstract}

Keywords

African nationalism, archive, ghost, play white, post-apartheid novel

About the author

Anette Horn is Professor of German at the University of the Witwatersrand. She has authored Rilke and The Knowledge of the Cosmopolites (both with Peter Horn), essays on South African literature and German literature from the eighteenth century to the present, and edited Like a House of Fire (South African Women's Writing).

The ghost is inextricably linked to ideology and the imagination. The ideology of Apartheid that was predicated on the racial superiority of Afrikaner whites becomes spectral when the repressed Other haunts the imagination of those on the right side of the racial divide. The spectral has to be seen in conjunction with religion; however, as Derrida points out, "If the ghost gives its form, that is to say, its body, to the ideologem, then it is the essential feature [le propre], so to speak, of the religious, according to Marx, that is missed when one effaces the semantics or the 
lexicon of the specter, as translations often do, with values deemed to be more or less equivalent (fantasmagorical, hallucinatory, fantastic, imaginary, and so on)" (1).

A connection exists between racism in South Africa and Christianity, at least the Christianity of Afrikaner nationalists, the ideology of the Dutch Reformed Church. The black Other is identified with the heathen or pagan, i.e., Christian monotheism as opposed to African ancestor worship, although there are other religions such as Judaism, Islam, and Hinduism, to name only the most prominent. Yet this is not the only form of religion, if one considers liberation theology, as other forms of religion and mythology give the imagination an inventive force. Therefore, as Derrida asserts, one "would still have to reckon with the invincible force and the original power of the 'ghost' effect. One would have to say why it frightens or strikes the imagination, and what fear, imagination, their subject, the life of their subject, and so forth, are" (1).

Samuelson views the sea as an archive of the Apartheid past that surfaced with the Truth and Reconciliation Commission in 1996, but it also submerged what could not be articulated within the discourse of African nationalism that dominates the present since 1994. "Once again, then, Wicomb figures the sea as an archive that surfaces histories submerged and drowned out by official narratives, and as a textual space capable of articulating the losses that remain unspeakable in the new national order" (553). In this sense, Zoë Wicomb goes beyond the imperative of truth and reconciliation that, although bringing the trauma of the victims of Apartheid to light, also silenced those traumas that challenged the new hegemony: the investigation of atrocities committed within the ANC in its detention camps (known as the Quattro camps), and the rape of women both within the liberation movement and by white security policemen, which the Gender Commission was supposed to address but which seem too painful for the victims to confront and work through, and too damaging for the new national order to fully acknowledge. It comes as no surprise, then, that the present is still haunted by the ghosts of the past. It also necessitates the work of mourning that can take the form of such narratives as Zoë Wicomb's novel Playing in the Light.

In this way, the story of Marion Campbell as a "play-white" - hence the title of the novel Playing in the Light, alluding also to Toni Morrison's Playing in the Dark-does not fit into the neat division between the perpetrator and the victim of Apartheid which the TRC favored-it shows the limited agency of the oppressed majority within the system of racial classification because lighterskinned coloreds, the descendants of white colonizers and black or Khoisan slaves or servants, can pass for white by being reclassified as white. While this brings with it certain privileges which whites enjoyed, such as access to better education and jobs, it also leads to unspeakable tragedy within these "play-white" families as they have to cut off all ties with their darker-skinned relatives. It thus throws their humanity into question in the sense that humane values are not observed within this context. A stunted personal growth and interpersonal relations is the result of the 
inhumane system of Apartheid and trying to play by its rules. In this sense, Marion Campbell comes to realize that she is hiding in the light rather than playing in it, as the fear of her "real" identity becoming public prevents her from enjoying her privileged status.

In order to uphold the lie of their white identity, Marion Campbell's mother has to deny her own mother's, Tokkie's, existence because of her dark skin by pretending that she is the family servant. To compound this tragedy, Tokkie complies with her daughter's deception, since she wants her daughter to have a better life than herself.

On the other hand, political activists such as Jeremy Cronin-distinguished poet, intellectual, Deputy Minister of Transport in the new Parliament, and Secretary of the Communist Party-questions the very distinction between perpetrator and victim of Apartheid in that it did not acknowledge the resistance against oppression by the liberation movement which included people irrespective of race and religion.

While Cronin draws on the division between the Apartheid state and the opponents of Apartheid, Wicomb shows the faultlines within the amorphous mass of the oppressed by probing their imbrication in the system of Apartheid. In this way she questions the national discourse of liberation which could become the new dominant discourse and opens up the possibilities that it would foreclose.

This implies that the post-Apartheid novel has the ability to interrogate new ways of looking at the past. The "post" in post-Apartheid therefore does not indicate a clean break with the past, but rather looks at stories that cut across such boundaries. It demonstrates that the past is not resolved in such gestures as the Truth and Reconciliation Commission, as important an event as this was, but was - as suggested in regard to the Gender Commission-not without its own silences and limitations. On the other hand, putting an end to the Apartheid past and opening a new chapter of democracy is a necessary and understandable move on the part of the tripartite alliance that constitutes the new government which consists of the labor organization, COSATU, the Communist Party, and by far the largest component, the ANC.

The post-Apartheid present is based on the TRC with its claim that the Apartheid past is over and has been dealt with, and that healing has occurred through the telling of one's story to the Commission. It thus has become part of the national archive. Derrida explicitly refers to the TRC in his book Archive Fever. Yet this archive should not be closed, but kept in the collective consciousness by remembering what was said and excavating that which has been left unsaid. Literature can play a crucial role in this project.

Thus Wicomb seems to take up the suggestion that novelist and academic André Brink made to writers in post-Apartheid South Africa: "creative writers were perhaps uniquely positioned to reach 'beyond facts' in engaging with the past; the 'real,' he argued, was not only merely that 
which could be excavated and represented, but needed actively to be 'imagined"' (qtd. in Van der Vlies 583). Van der Vlies sees Wicomb's novels as a prime example of this new perspective on the past, although one must add that she did not do so in direct response to Brink, as van der Vlies suggests. Her first collection of short stories You Can't Get Lost in Cape Town already demonstrates a narrative stance that is quite distinct from Brink's or Gordimer's. Nevertheless, van der Vlies is correct to state that her novels David's Story and Playing in the Light might be seen as "a sensitive and imaginative engagement with the archive, and in a manner that is particularly rewarding to scholars interested in the literary mediation of ideas of history and in narrative encounters with notions of 'truth' in post-apartheid South Africa" (848).

Wicomb is too subtle and sophisticated a writer to allow her readers to take her fictions at face value. Thus, she plays with author's position, narratorial voice, and focalizers in Playing in the Light. In this regard, the novel must be placed within postmodernism which is all too aware of its own devices as to make the reader believe in a naïve representation of reality and the truth. Besides, Wicomb is a Professor of literature at the University of Strathclyde in Scotland with many critical essays to her name wherein she interrogates the assumptions underlying discourses on postcolonialism and representations of race and gender. This does not imply, however, that one can apply her critical essays directly to her fiction, or-put differently - that her fiction is an illustration of her theoretical positions.

Marion Campbell's life is disrupted by the specter of an unfamiliar yet uncannily familiar face on the ocean of her apartment in Blouberg, an upmarket suburb where mainly wealthy white Afrikaners live, ironically with a direct view of Robben Island, where political prisoners were kept. This strange apparition or ghost manifests itself at first as a ringing in her ears and a gagging in the curtains of her four-poster bed, a symbol of her cocooned life of privilege which she has styled according to lifestyle magazines. As the reader learns in the course of the novel, this life is also lonely and bland: "But lately, the four-poster bed has turned against her. There have been times, propped up with her magazines, when something buzzes in her ears, a sense of swarming that grows louder and louder, even as the sunset, which she can see from the bed, curls in serene pink and gold across the horizon and the cool Atlantic laps at Robben Island. Then, for a moment, she seems to gag on meters of muslin, ensnared in the fabric that wraps itself round and round her into a shroud from which she struggles to escape" (2).

After she has seen the face and the story of Patricia Williams in a daily newspaper which she keeps on postponing to read and - when she does - is horrified by the "unspeakable ways" of her torture as a political woman prisoner, and of whom Marion says that "the ghost of the past hovers in her gaze," the memory of her nightmares returns: "The sea is restless, the tide is full; a small cluster of lights on Robben Island winks drunkenly. From her balcony, she stares in horror at an 
enlarged face floating on the water, a disfigured face on the undulating waves, swollen with water" (55).

This distorted image is conflated with Marion's dream of a shapeless woman whom she cannot name as this memory is repressed. Nevertheless, it triggers a recognition or a need to know who Tokkie was from her father. She senses that a private truth has been withheld from her, although here the private is also the political. In her dreams, the uncanny is expressed in her sense of disorientation: "But in the kitchen there is the smell of coffee beans just roasted and the palpable absence of a woman who threatens to materialize, first here and then there, someone who moves between a central table and a black Dover stove, a darkening, a thickening outline perhaps, but no, then the air thins out, swept into uniformity. Marion keeps going out to the stop to get away from the shape of the woman, but cannot tell whether it is the back or the front of the house, and so must return indoors." The ghostly woman in her dream "does not speak and ... does not want to speak" (30).

Marion surmises that "perhaps it is the woman in the dream who triggers the memory of their girl, Tokkie; she should not say girl since Tokkie was already an old woman, hence her mother unusual indulgence." Little does she realize the real and tragic reason for this indulgence. It is ironic when Marion as focalizer at this point of the narrative should call Tokkie a family servant who "was part of their family so to speak." ${ }^{1}$ However, she is too old to do any domestic work in the house and Marion imagines that "she came once a week to see them and keep an eye on things in the Observatory house." Yet Tokkie seems to lend flavor and color to Marion's life by sitting in her wicker chair in the backyard of the house, on a "shawl of multi-colored squares she had crocheted for Helen [Tokkie's daughter and Marion's mother] from scraps of wool" and "shelling peas that rattled into the pot, or holding between her knees an enamel bowl in which egg whites were beaten into peaks of snow. Ah, she would sigh contentedly, slipping off her shoes and wiggling her feet, it's so lovely and cool here in the shade. Tokkie would peel an orange in an unbroken spiral that Marion rearranged into a whole to fool her father. The old woman fed the little girl segments of orange with the membrane removed. Waste not, want not, she said, nibbling at the peel, from which fragrant citrus oil spurted" (31).

This smell of orange is conjured up by the face on the ocean, "a smell of orange, the zest of freshly peeled orange skin, wafts up from the shore, mingling with the brine," which sets off the memory of a different Tokkie, distant and stern: "It is not until she goes back indoors that recognition beats like a wave against the picture window: Tokkie, it is Tokkie's face on the water. Not the smiling, doting woman who holds her tightly against a breast doused in the orangeblossom cologne that Helen gives her on her birthdays; but rather the stern face that the little girl, squatting in the grass where she's made a marvelous structure of stick, glances up at. That face, lost 
in reverie, starts as the child calls repeatedly, impatiently, Tokkie, Tokkie, look. The dear face that looks down and for a moment is lost, does not know her, so that the child, whose heart explodes, smashes her tepee of sticks and runs indoors to hide under her bed, where Tokkie must find her and kiss her better" (55).

This memory jolts Marion out of her reverie and makes her phone her father to find out what Tokkie's real name was, as servants were often given nicknames by their employers who couldn't pronounce their African names or because one simply did not want to know their real identity. Also, the Afrikaans diminutive "ie" in Tokkie indicates that the servant was seen on the same level as a child, as "part of the family." Yet the name Tokkie also alludes to the tokoloshe of African mythology where it symbolizes a demon that enters people's dreams at night so that they are seen to be possessed by this spirit. In this sense, Tokkie is a ghost or spirit in both senses of the word: as the repressed past in Marion's life, and in the real sense that Tokkie is a demon. This shows how complex reality is where the real is also the mythological. One might say that the real of Apartheid is a myth based on the myth of racial superiority, which had tragic consequences in real life, and that the mythology of the ghost, the tokoloshe, is real because it is the repressed Other that returns to haunt the white master or colonizer and exacts its due.

This could be seen in the African National Congress becoming the ruling party after 1994 with many of its leading members taking official positions in government, and also in the opportunities in the private industry becoming available to black entrepreneurs. Thus Patricia Williams becomes ambassador to Finland and Marion meets a black businessman, Vumi, whose black BMW - a symbol of success for blacks - she bumps into. When she meets him again in Glasgow where she has gone to retrace her Scottish roots, he is busy securing an important Black Economic Empowerment (BEE) oil-deal. In contrast to many post-Apartheid writers ${ }^{2}$ who send up black diamonds, as these blacks who profited from BEE deals are called, Wicomb or at least her focalizer, Marion, who is herself a successful businesswoman and who has at the time of meeting Vumi come to accept her Griqua and Scottish identity, does not seem to have a problem with this. 
1. Meg Samuelson refers to this trite expression used by whites which made domestic exploitation seem bearable at least to the employers.

2. An excellent example of such a satire is Zakes Mda's novel Black Diamond where he takes a sardonic look behind the scenes of the new black elite through the focus of a liberation army fighter who works for a security company and his BEE girlfriend who will do everything to get a licence for her own television station.

\section{WORKS CITED}

Derrida, Jacques. The Specters of Marx: The State of the Debt, the Work of Mourning, and the New International. Trans. Peggy Kamuf. New York: Routledge, 1994. Print.

Samuelson, Meg. "Oceanic Histories and Protean Poetics: The Surge of the Sea in Zoë Wicomb's Fiction." Journal of Southern African Studies 36.3 (2010): 543-57. Taylor and Francis Online. Web. 30 Jan. 2012.

Van der Vlies, Andrew. “The Archive, the Spectral, and Narrative Responsibility in Zoë Wicomb's Playing in the Light." Journal of Southern African Studies 36.3 (2010): 583-98. Taylor and Francis Online. Web. 30 Jan. 2012.

Wicomb, Zoë. Playing in the Light. New York: New Press, 2008. Print. 